\title{
Scale Development of Teachers' Sense Meaning at Work in Taiwan-From the Perspective of Workplace Spirituality
}

\author{
Wu Ho-Tang ${ }^{1}$, Chou Mei-Jü,* \\ ${ }^{1}$ Department of Education, National Kaohsiung Normal University, Taiwan \\ ${ }^{2}$ Department of Early Childhood Education and Center for Teacher Education, National Pingtung University, Taiwan
}

Copyright $(\mathcal{C} 2015$ by authors, all rights reserved. Authors agree that this article remains permanently open access under the terms of the Creative Commons Attribution License 4.0 International License

\begin{abstract}
For the importance of developing people's potential in working, the study aims to develop the scale of meaning sense at work. Three steps are adopted: $\mathbf{1}$. Literature analysis: with foreign research analysis of EFA, it revealed that Spirituality at Work can be classified into 3 levels, including the individual, the group, and the organization level. From Milliman, Czaplewski, and Ferguson's perspective, the individual level explores sense of meaning at work, including energy obtained from work, the enjoyable work, and the meaning that work endows the individual. At this point, the research integrate the aspects of the individual scales of spirituality at work as sense of attraction at work, sense of pleasure at work, and sense of inner life. 2. Expert review: After consulting the items of scale of spirituality at work, we proposed the draft of 13-item Three Factor Questionnaire. Then, the questionnaire was reviewed and modified by three university scholars who had published paper or books regarding spirituality to provide us their comment for further modification. Subsequently, a senior high school teacher with consultation and life education major offered us practical opinions at the education site. Finally, one item was deleted, 6 items' terms were modified, and 6 remained the same. 3. CFA: This part is categorized into three models. (1) The initial model: the 12 items of Three Factors were edited as 5 point scale. After investigating 235 teachers, we conducted the first-order CFA model to verify the fitness. The results of the overall model are fairly appropriate. However, the factor load of "I often forget time for teaching or processing administrative matters" is .29, so we deleted this item. (2) The modification model: The model after deleting the item is called the modification model, and the results are fairly appropriate. With further analyzing the basic fit of the modification model, it is found that there is no offending estimation. The fit of the internal structure is acceptable (including individual reliability, composite reliability, the average variation extraction, and construct discrimination). 3 . The cross-validity model: since the model had been
\end{abstract}

modified, we investigated another batch of samples $(N=378)$ to confirm the stability of the model. The overall results are fairly appropriate. Here, the three factor teacher's sense of meaning at work with 11 items are set up; that is, the three factor teacher's sense of meaning at work with 11 items is supported, which is classified into sense of attraction at work (4 items), sense of pleasure at work (4 items), and sense of inner life (3 items).

Keywords CFA, Sense of Meaning at Work, Workplace Spirituality

\section{Introduction}

Work is the key component for most people in regard to financial, social and wellbeing matters (Beigi, Shahbolaghi, Rassafiani, Haghgoo, \& Taherkhani, 2015)[1]. Most importantly, work makes people experience sense of meaning at work, which means people own sense of satisfaction and happiness when they are working (Ashmos \& Duchon, 2000)[2]. As McLaughlin (1998)[3] claimed, if the organization strives to survive in the $21^{\text {th }}$ century, it must have its employees feel that work is meaningful and purposeful, because a potential employee will seek for a workplace that he or she can show the personal inner values. Hawley (1993)[4] also considered that meaningful work is a kind of enjoyment, because one can be energized by work. When lack of meaning at work, people will have alienation (Aktouf, 1992)[5], and further, the workforce cannot perform at its potential (Sikka, Morath, \& Leape, 2015)[6]. People will gain buffer where greater meaning making at work was associated with weaker relations between work stress and the presence of meaning in life (Allan, Douglass, Duffy, \& McCarty, 2015)[7]. Generally, meanings of work were positively related to the likelihood to engage in post-retirement employment (Fasbender, Wang, Voltmer, \& 
Deller, 2015)[8]. The reason of work volition related to job satisfaction was from stronger perceived fit with one's work environment and greater perceived meaning at work (Duffy, Autin, \& Bott, 2015)[9].

According to what mentioned above, we have learned that sense of meaning at work is quite important, although there are no studies on sense of meaning at work with the teachers as the research subject. Therefore, a teacher's sense of meaning at work serving as the research tool will be helpful to research on such topic.

Regarding sense of meaning at work, there are a variety of theoretical foundations, like Ros, Schwartz, and Surkiss's (1999)[10] research on the theory of basic individual values. They consider that work goals or values are specific expressions of general values in the work setting, and their Work Values Survey can be categorized into four dimensions: 1. the social dimension, with three themes involving contributing to people and society, work with people, and social contact with co-workers; 2 . the extrinsic with two themes-- good salary and work conditions and job security (permanent job and pension); and 3. prestige, including two subjects authority to make decisions over people and prestigious and highly valued work; 4 . the intrinsic, like interesting and varied work and work in which you are your own boss. In addition, meaning at work refers to the value of a work goal or purpose, judged in relation to an individual's own ideals or standards (Thomas \& Velthouse,1990)[11], which was adopted by Spreitzer (1995)[12] to compile the Scale of Psychological Empowerment in the Workplace. With meaning at work as one of the three dimensions as follows: 1 . the work I do is very important to me; 2 . my job activities are personally meaningful to me; and 3. the work I do is meaningful to me. Harris, Kacmar, and Zivnuska (2007)[13] applied these three dimensions as well, exploring abusive supervision as a predictor of performance and the meaning of work as a moderator of the relationship.

Based on human needs theory and developmental theory, as Mor-Barak (1995)[14] developed the concept of meaning of work, combined Alderfer's human needs theory and Erikson's developmental theory to create four factors of work meaning (social, personal, financial, and generative meaning of work). Also, Fasbender et al. (2015)[8] extended this theme, and divided sense of meaning at work-- 1.Social meaning: the items were presented by "having contact with others," "being accepted and appreciated," and "fulfilling expectations of others"; 2. Personal meaning: the statements were introduced with the following sentences "for me personally, work means ....", "having a meaningful task", and "finding personal satisfaction; 3. financial meaning, which is illustrated with "earning money"; 4.generative meaning: which subjects are "teaching younger workers," "passing the knowledge to the next generation," "sharing ability with younger," and "contributing to society.
For hedonic (pleasure-oriented) and eudaimonic (growthand purpose-oriented) viewpoint, Steger, Dik, \& Duffy (2012) [15] defined work as not as simply whatever work means to people (meaning), but as work that is both significant and positive in valence (meaningfulness). The Work and Meaning Inventory (WAMI) developed by the three authors has a total of 10 items, and is classified into three dimensions: 1. Positive Meaning with "I have found a meaningful career," "I understand how my work contributes to my life's meaning." and "I have a good sense of what makes my job meaningful," and "I have discovered work that has a satisfying purpose;" 2. Meaning-Making through Work with "I view my work as contributing to my personal growth," "my work helps me better understand myself," "my work helps me make sense of the world around me;" 3. Greater Good Motivations with "my work really makes no difference in the world," "I know my work makes a positive difference in the world," and "the work I do serves a greater purpose."

To discuss sense of meaning at work from the angle of workplace spirituality, Scale of Spirituality at Work compiled by Ashmos \& Duchon (2000)[2] has influenced on the subsequent studies on work spirituality (Table 1).

From the analysis above, it has been found that the theoretical foundation of sense of meaning at work is consist of values, human needs theory, developmental theory, hedonic, eudaimonic, and spirituality. The latter focuses on raising the personal inner spirituality, regardless of good salary and work conditions, job security (permanent job, pension), or prestige such as authority to make decisions over people, prestigious, and highly valued work. In addition, the wage, work duration, and the pension system are all protected by laws in Taiwan teachers. On the other hand, teachers in Taiwan belong to high socio-economic status, they enjoy high prestige, and the job is a kind of highly valued "elite-cultivated work ". Consequently, this research compiled Sense of Meaning at Work Scale from the perspective of spirituality.

\section{Literature Discussion}

Spirituality-based sense of meaning at work often appear in some scales of workplace spirituality, which involves the effort to find one's ultimate purpose in life, to develop a strong connection to coworkers and other people associated with work, and to have consistency (or alignment) between one's core beliefs and the values of their organization (Mitroff \& Denton, 1999)[16]. Since Ashmos \& Duchon (2000)[2] edited the Scale of Spirituality at Work, many scales are designed by adapting this scale. The scales of workplace Spirituality after 2000 have been organized in Table 1. 
Table 1. Scale of workplace Spirituality

\begin{tabular}{|c|c|c|c|c|c|}
\hline Name & Year & Scale & Subject & $\begin{array}{l}\text { Statistic } \\
\text { Method } \\
\end{array}$ & Dimension and Title \\
\hline Ashmos \& Duchon & $2000[2]$ & Spirituality at Work & $\begin{array}{c}\text { Employees in the } \\
\text { hospital }\end{array}$ & $\begin{array}{l}\text { Exploratory } \\
\text { factor analysis } \\
\text { (EFA) }\end{array}$ & $\begin{array}{l}\text { 1. Meaningful work } \\
\text { 2. Community } \\
\text { 3. Inner life }\end{array}$ \\
\hline $\begin{array}{l}\text { Milliman, } \\
\text { Czaplewski,, \& } \\
\text { Ferguson }\end{array}$ & $\begin{array}{l}2003 \\
{[17]}\end{array}$ & $\begin{array}{l}\text { Workplace Spirituality } \\
\text { Scale }\end{array}$ & EMBA & $\begin{array}{l}\text { Confirmatory } \\
\text { factor } \\
\text { analysis(CFA) }\end{array}$ & $\begin{array}{l}\text { 1. Meaningful work } \\
\text { 2. Sense of community } \\
\text { 3. Alignment with organizational values }\end{array}$ \\
\hline Sheep & $\begin{array}{l}2004 \\
{[18]}\end{array}$ & $\begin{array}{l}\text { Workplace Spirituality } \\
\text { Person-Organization } \\
\text { Fit Scale }\end{array}$ & Undergraduates & $\begin{array}{l}\text { EFA } \\
\text { CFA }\end{array}$ & $\begin{array}{l}\text { 1.Sself-workplace integration } \\
\text { 2. Meaning in work } \\
\text { 3. Transcendence of self } \\
\text { 4. Growth and development }\end{array}$ \\
\hline Duchon, \& Plowman & $\begin{array}{l}2005 \\
{[19]}\end{array}$ & $\begin{array}{l}\text { Meaning and Purpose } \\
\text { at Work Questionnaire }\end{array}$ & $\begin{array}{l}\text { Employees in the } \\
\text { hospital }\end{array}$ & $\begin{array}{l}\text { Cronbach's } \\
\text { Coefficient } \\
\text { Alpha }\end{array}$ & $\begin{array}{l}\text { 1. Meaning at work } \\
\text { 2. Community } \\
\text { 3. Inner life } \\
\text { 4. Work unit community } \\
\text { 5. Work unit and meaningful work }\end{array}$ \\
\hline $\begin{array}{l}\text { Kinjerski \& } \\
\text { Skrypnek }\end{array}$ & $\begin{array}{l}2006 \\
{[20]}\end{array}$ & Spirit at Work Scale) & $\begin{array}{c}\text { employees of } \\
\text { university }\end{array}$ & EFA & $\begin{array}{l}\text { 1. Engaging work } \\
\text { 2. Community } \\
\text { 3. Mystic experience } \\
\text { 4. Spiritual connection } \\
\end{array}$ \\
\hline Name & Year & Title & Subject & $\begin{array}{l}\text { Statistic } \\
\text { Method }\end{array}$ & Dimension and Title \\
\hline Moore \& Casper & $\begin{array}{l}2006 \\
{[21]}\end{array}$ & $\begin{array}{l}\text { Workplace Spirituality } \\
\text { Scale }\end{array}$ & $\begin{array}{l}\text { Company } \\
\text { employees }\end{array}$ & $\begin{array}{l}\text { Cronbach's } \\
\text { Coefficient } \\
\text { Alpha }\end{array}$ & $\begin{array}{l}\text { 1.Self-work immersion } \\
\text { 2.Interconnectedness } \\
\text { 3. Self-Actualization }\end{array}$ \\
\hline Rego \& e Cunha & $2008[22]$ & $\begin{array}{l}\text { Scale of Spirituality at } \\
\text { Work }\end{array}$ & $\begin{array}{l}\text { Company } \\
\text { employees }\end{array}$ & EFA & $\begin{array}{l}\text { 1. Team's sense of community } \\
\text { 2. Alignment between organizational and } \\
\text { individual value } \\
\text { 3. Sense of contribution to the community } \\
\text { 4. Sense of enjoyment at work }\end{array}$ \\
\hline Pawar & $\begin{array}{l}2009 \\
{[23]}\end{array}$ & Workplace Spirituality & $\begin{array}{l}\text { Company } \\
\text { employees }\end{array}$ & $\begin{array}{l}\text { Cronbach's } \\
\text { Coefficient } \\
\text { Alpha }\end{array}$ & $\begin{array}{l}\text { 1.Meaning in work } \\
\text { 2. Community at work } \\
\text { 3. Positive organizational purpose }\end{array}$ \\
\hline $\begin{array}{l}\text { Petchsawanga \& } \\
\text { Duchon }\end{array}$ & $\begin{array}{l}2009 \\
{[24]}\end{array}$ & $\begin{array}{l}\text { Scale of Spirituality at } \\
\text { Work }\end{array}$ & $\begin{array}{l}\text { Company } \\
\text { employees }\end{array}$ & CFA & $\begin{array}{l}\text { 1. Compassion } \\
\text { 2. Meaningful work } \\
\text { 3. Mindfulness } \\
\text { 4. Transcendence }\end{array}$ \\
\hline Abdullah \& Ismail & $\begin{array}{l}2013 \\
{[25]}\end{array}$ & $\begin{array}{l}\text { Scale of Malay Version } \\
\text { Workplace Spirituality }\end{array}$ & Teachers & $\begin{array}{l}\text { EFA } \\
\text { CFA }\end{array}$ & $\begin{array}{l}\text { 1. Work Meaningful Dimension } \\
\text { 2.. Community Sense Dimension) } \\
\text { 3. Coherent of Organizational Value } \\
\text { Dimension }\end{array}$ \\
\hline Piryaei \& Zare & $\begin{array}{l}2013 \\
{[26]}\end{array}$ & Workplace Spirituality & $\begin{array}{l}\text { Company } \\
\text { employees }\end{array}$ & $\begin{array}{l}\text { Cronbach's } \\
\text { Coefficient } \\
\text { Alpha }\end{array}$ & $\begin{array}{c}\text { 1. Meaningful work } \\
\text { 2. Sense of community } \\
\text { 3.Positive organizational purpose }\end{array}$ \\
\hline
\end{tabular}

The number of dimensions in the scales in Table 1 differs between 3-7, mostly 3, because of EFA. Besides, Milliman et al.(2003)[17] consider that workplace spirituality has three dimensions: 1. Individual level--meaning at work, including enjoying work, energized by work, and work giving personal meaning and purpose; 2. Group Level-sense of community, including sense of connection with co-workers, employees supporting each other, and being linked with a common purpose; 3. Organization Level--alignment with organization values like feeling connected to organization's goals, identifying with organization's mission and values, and organization caring about employees. At this point, sense of meaning at work is the individual level in workplace spirituality, including enjoying work, energized by work, work giving personal meaning and purpose. Also, the individual level in Table 1 
includes: self-workplace integration, engaging work, sense of enjoyment at work, and mindfulness, self-work immersion, mystic experience, self-fulfillment, transcendence of self, growth and development, inner life, and spiritual connection. Although the terms are different, they overlap with one another. According to Milliman et al., the terms can be classified into three items:

\section{Sense of Engaging Work}

Sense of engaging work comes from Kinjerski \& Skrypnek's (2006)[20] dimension of engaging work in spirit at work scale. They indicated that engaging work seemed to reflect primarily the cognitive dimension from the definition which was characterized by a sense of being authentic, (e.g. "I bring my whole self (mind, body, and spirit) to work", an awareness of alignment between one's values and beliefs and one's work (e.g., "I experience a match between the requirements of my work and my values, beliefs, and behaviors"), and a belief that one is engaged in meaningful work that has a higher purpose (e.g., "I am engaged in work that has a higher purpose"). Engaging work also included a couple of items that were intended to measure positive affect, that in hindsight could be labeled enjoyment and fulfillment through work (e.g., "I am passionate about my work" and "I feel nourished by my work") It is what Milliman et al.(2003)[17] called energized by work; that is, work can bring energy, vitality, spirit, so people expect and love to work. This research also adopted engaging work as the dimension, called sense of engaging work, meaning the engaging work is attractive, and makes people expect to work.

\section{Sense of Enjoyment at Work}

Sense of enjoyment at work comes from Rego \& e Cunha's (2008)[22] Spirituality at Work Scale. It comprises items related to the sense of joy and pleasure at work. It is a sub-dimension of the larger dimension identified by Milliman et al. (2003)[17] and Ashmos and Duchon (2000)[2] as "Meaningful work". It represents a different way to achieve meaning at work, and it is the same in Kinjerski \& Skrypnek's (2006)[20] Spirit at Work Scale, dimension of mystical experience. From the items in the scale, "at times, I experience a "high" at my work," "I have moments at work in which I have no sense of time or space," "at moments, I experience complete joy and ecstasy at work," "I experience moments at work where everything is blissful," "at times, I experience an energy or vitality at work that is difficult to describe." Such items have the same meaning with the flow in positive psychology. Fullagar \& Kelloway (2009)[27] considered that flow is like Maslow's peak experience, self-actualization, both stressing the sense of fulfillment and enjoyment when the individual is engaging in activities or seeking for the self. Besides, Petchsawanga and Duchon (2009)[24] mentioned that the dimension of transcendence in their scale is what Kinjerski and Skrypnek (2006)[20] said about dimension of mystical experience. Therefore. this research organized enjoyment at work, self-actualization, transcendence, and mystical experience, calling "sense of enjoyment at work," meaning people the sense of fulfillment and enjoyment when they are engaging themselves into work.

\section{Sense of Inner Life}

Milliman et al. (2003)[17] mentioned that work gives personal meaning and purpose, which is so-called inner life proposed by Ashmos and Duchon (2000)[2]. They thought that people found being in work, making them enrich their inner and outer life, and making them feel meaningful existence. Therefore, growth and development, inner life, and spiritual connection all enhance the individual's meaning of existence, and called as sense of inner life in this research, referring to the rich inner life brought by work.

To sum up, from the workplace spirituality viewpoint based on Milliman et al's (2003)[17] individual level, the scale was developed. They thought that sense of meaning at work should contain enjoying work, energized by work, and work giving personal meaning and purpose. After consulting the related scales, this research also proposed sense of engaging work, sense of enjoyment at work, and sense of inner life. We defined sense of meaning at work as sense of satisfaction and happiness at work that makes people's life even more meaningful and purposeful. As for out scale, as the scores of sense of engaging work, sense of enjoyment at work, and sense of inner life increase, the score of sense of meaning at work becomes higher.

\section{Research Design}

\section{(1) Review of Item Pool by Experts}

Regarding development of Sense of Meaning at Work Scale, after drafted according to literature, we had it reviewed by Professor Shiao, Professor Luo, and Professor Chen (serving in university, all publishing articles or books about spirituality) to provide opinions based on theories. Besides, we consulted Teacher Lu (senior high school teacher with life education major) for practical opinions.

\section{(2) Research Samples}

Sense of Meaning at Work Scale was investigated twice, the participants rated how they agree with each item was for them along a 5-point scale ranging from " $1=$ unagree", " $2=$ a little bit agree", " $3=$ partially agree", " $4=$ mostly agree" to " $5=$ completely agree": 1 . In the first round: investigated with pretest questionnaires for the initial model. The sample is 235 people. 2 . In the second round: in the first CFA, we deleted one item to modify the initial model. Then, we had to investigate another batch of samples $(N=378)$ for review, For SEM sample number, Schumacker and Lomax (1996)[28] thought that most SEM sample number ranges between 200 to 500, and our samples met such claim.

The background allocation of the two batches of samples are as Table 2 shows: 
Table 2. The Background Allocation of the Two Batches of Samples of Meaning at Work Scale

\begin{tabular}{|c|c|c|c|c|c|}
\hline & & \multicolumn{2}{|c|}{$1^{\text {st }}$ Investigation $(N=235)$} & \multicolumn{2}{|c|}{$2^{\text {nd }}$ Investigation $(N=378)$} \\
\hline & & Times & $\%$ & Times & $\%$ \\
\hline \multirow{3}{*}{ Gender } & 1. Male & 60 & 25.5 & 122 & 32.3 \\
\hline & 2.Female & 174 & 74.0 & 255 & 67.5 \\
\hline & 1.Elementary & 120 & 51.1 & 141 & 37.3 \\
\hline \multirow[t]{2}{*}{ School Level } & 2.Junior High & 64 & 27.2 & 131 & 34.7 \\
\hline & 3.Senior High & 50 & 21.3 & 106 & 28.0 \\
\hline \multirow{2}{*}{ Also Administrative Personnel } & 1.No & 93 & 39.6 & 166 & 43.9 \\
\hline & 2. Yes & 140 & 59.6 & 212 & 56.1 \\
\hline \multirow{2}{*}{ Marital Status } & 1. Married & 52 & 22.1 & 23.0 & 23.2 \\
\hline & 2. Unmarried & 179 & 76.2 & 76.2 & 76.8 \\
\hline Length of service & & $M=16.82$ & $S D=7.64$ & $M=13.54$ & $S D=8.62$ \\
\hline
\end{tabular}

\section{(3) Data Process}

The first-order CFA model was employed to examine the three proposed dimensions of meaning at work: Sense of Engaging Work, Sense of Enjoyment at Work, Sense of Inner Life. The analysis included assessing the model fit, modifying the model fit, re-verifying the modified model fit. The initial measurement model consisted of three latent variables with their indicators: Sense of Enjoyment at Work (five indicators), Sense of Engaging Work (four indicators), Sense of Inner Life (three indicators).

\section{Results and Discussion}

\section{(1)Review of Item Pool by Experts}

After hiring four experts to review the draft of the items, if any of them considered any item should be deleted, we deleted it. There are 13 items in the initial draft, we deleted one according to the review results, the $6^{\text {th }}$ of the sense of enjoyment at work dimension, "teaching (or administration) makes me energetic," because it means the same with the $2^{\text {nd }}$ item of the same dimension "I expect to teach (or process administration) in the school." Besides, six items were modified, such as "I expect to teach (or process administration) in school" was modified as "I expect to work in school." At last, 6 items remain the same.

Table 3. Results of Review of item pool by experts

\begin{tabular}{|c|c|c|c|c|}
\hline Dimension & The original & Review results & $\begin{array}{l}\text { initial } \\
\text { model code }\end{array}$ & $\begin{array}{l}\text { cross- validity of the } \\
\text { model code }\end{array}$ \\
\hline \multirow{6}{*}{$\begin{array}{l}\text { Sense of } \\
\text { enjoyment } \\
\text { at work }\end{array}$} & I often go to school happily & Remained the same & MW1 & MW1 \\
\hline & $\begin{array}{l}\text { Teaching (or administration) always } \\
\text { makes me happy }\end{array}$ & $\begin{array}{l}\text { Modified as: } \\
\text { 2. Teaching (or administration) always makes } \\
\text { me enjoyable }\end{array}$ & MW2 & MW2 \\
\hline & $\begin{array}{l}\text { Teaching (or administration) always } \\
\text { makes forget time }\end{array}$ & $\begin{array}{l}\text { Modified as: } \\
\text { 3. I often forget time because of teaching (or } \\
\text { administration) }\end{array}$ & MW3 & $\begin{array}{l}\text { initial model deleted } \\
\text { for low factor } \\
\text { loading }\end{array}$ \\
\hline & $\begin{array}{l}\text { I am energetic in teaching (or } \\
\text { administration) }\end{array}$ & $\begin{array}{l}\text { Modified as: } \\
4 . \quad \text { I teach (or process administration) } \\
\text { energetically }\end{array}$ & MW4 & MW3 \\
\hline & $\begin{array}{l}\text { I feel everything is good when I am } \\
\text { working }\end{array}$ & Remain the same & MW5 & MW4 \\
\hline & $\begin{array}{l}\text { I am often high-spirited in teaching (or } \\
\text { administration) }\end{array}$ & Deleted(the same with Item 2) & & \\
\hline \multirow[t]{4}{*}{$\begin{array}{l}\text { Sense of } \\
\text { engaging } \\
\text { work }\end{array}$} & $\begin{array}{l}\text { Teaching (or administration) meet my } \\
\text { value of education and faith }\end{array}$ & Remain the same & MW6 & MW5 \\
\hline & $\begin{array}{l}\text { I expect to teach (or process } \\
\text { administration) in school }\end{array}$ & $\begin{array}{l}\text { Modified as: } \\
\text { 7. I expect to work in school }\end{array}$ & MW7 & MW6 \\
\hline & I love educational work & Remain the same & MW8 & MW7 \\
\hline & The position now meet my expectation & $\begin{array}{l}\text { Modified as: } \\
10 . \text { My position now enhance enjoyment in life. }\end{array}$ & MW9 & MW8 \\
\hline \multirow[t]{3}{*}{$\begin{array}{l}\text { sense of } \\
\text { inner life }\end{array}$} & $\begin{array}{l}\text { Educational work makes me plays an } \\
\text { important part in my life }\end{array}$ & $\begin{array}{l}\text { Modified as: } \\
\text { 13. Educational work makes me is the most } \\
\text { important part in my life. }\end{array}$ & MW10 & MW9 \\
\hline & $\begin{array}{l}\text { Educational work makes me happier and } \\
\text { more satisfied }\end{array}$ & Remain the same & MW11 & MW10 \\
\hline & $\begin{array}{l}\text { Educational work makes me know more } \\
\text { about myself }\end{array}$ & Remain the same & MW12 & MW11 \\
\hline
\end{tabular}




\section{(2) CFA Test}

\section{A. The Latent Variable's Correlation Coefficient}

We summed up the scores of dimensions of sense of meaning at work scale to conduct correlation coefficient, and the results show the correlation of the three latent variable is between .63-.77, and all achieve significantly positive correlation $(p<.001)$ (See Table 4$)$.

Table 4. The Correlation Coefficient of the Three Latent Variables of Sense of Meaning at Work Scale and Descriptive Data

\begin{tabular}{cccccc}
\hline Item \& No. & 1 & 2 & 3 & $M$ & $S D$ \\
\hline $\begin{array}{c}\text { 1. Sense of enjoyment at } \\
\text { work }\end{array}$ & 1 & & & 18.08 & 2.86 \\
2. Sense of engaging work & $.77^{* * *}$ & 1 & & 14.66 & 2.64 \\
3. Sense of inner life & $.63^{* * *}$ & $.77 * * *$ & 1 & 11.42 & 1.96 \\
\hline
\end{tabular}

$N=235 . * * * p<.001$.

(3) The Initial Model Test

The model with 12 items in Three Factor after reviewed by the experts is called the initial model. After investigating 235 teachers, we verifies them by CFA. By correlation coefficient analysis, we confirmed that there is significantly positive correlation between the three latent variables and the total score. The inspection results are (See Fig. 1) are: On overall fit of the initial model, $\chi^{2}=128.55, d f=51, p=.00$, $\mathrm{GFI}=.92, \mathrm{AGFI}=.88, \mathrm{RMSEA}=.08, \mathrm{IFI}=.95, \mathrm{TLI}=.93$, and $\mathrm{CFI}=.95$. Among them, $\chi^{2}$ achieves significantly level, not meeting the standard of more than .90 ; $\mathrm{AGFI}=.85$, not meeting the standard of more than .90 .

To observe the 12 indicators' factor loading, the factor loading of "MW3"(the item is "I often forget time because of teaching or (administration)") is .29, and the determining coefficient is .08 , not reaching $10 \%$. Bogozzi and $\mathrm{Yi}$ (1988)[29] proposed the factor loading among the indicators should range between .50-.95, and Tabachnica and Fidell (2007)[30] considered that when $\lambda \geqq .55$, it can be regarded as good. To consider the appropriateness, the inner quality, and the standard of $\lambda \geqq .55$ of the overall model proposed by Tabachnica and Fidell, MW3 was deleted.

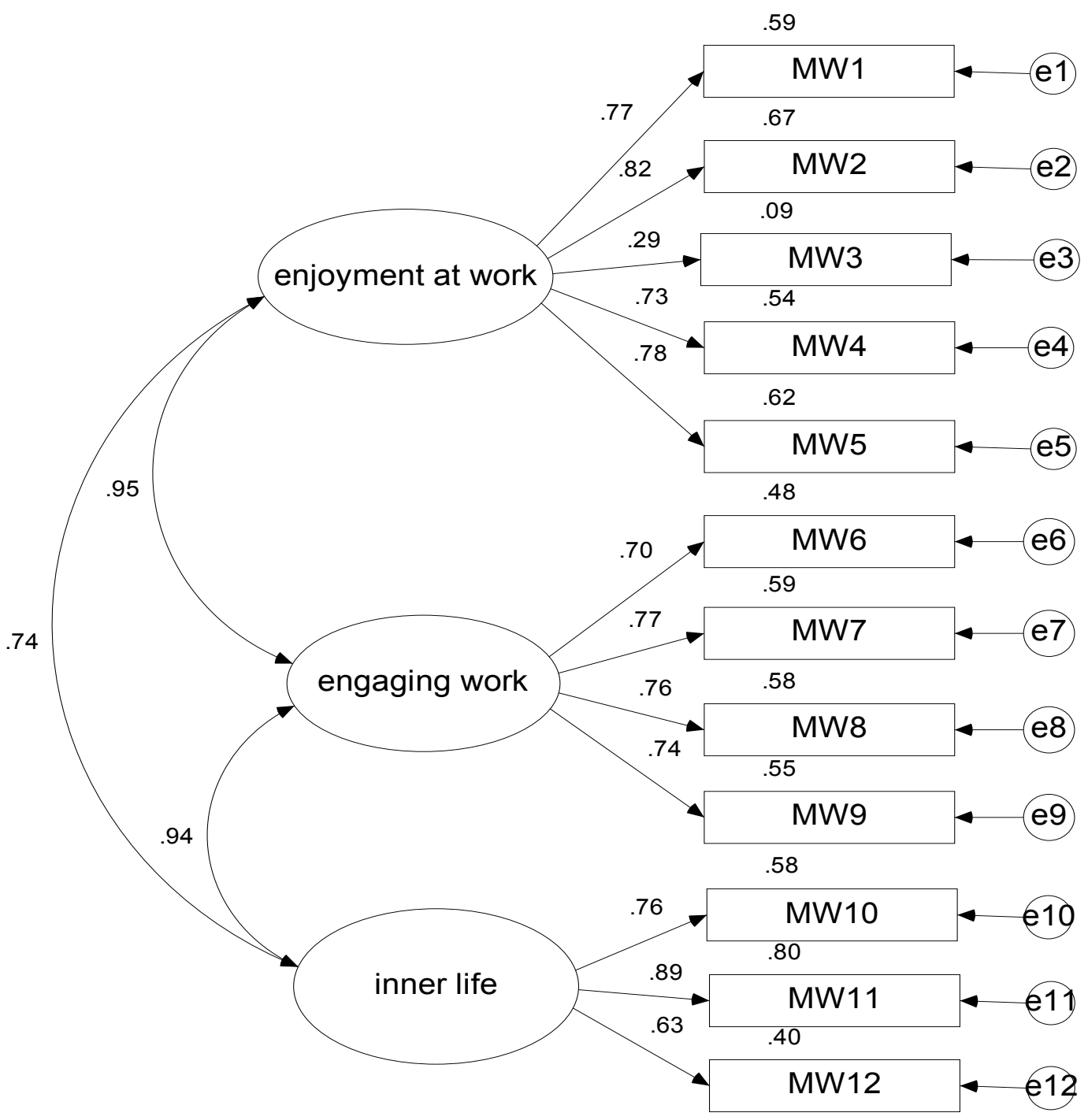

Note: Data on the indicators is individual reliability

Figure 1. The initial model's fit evaluation (standardized estimates) 


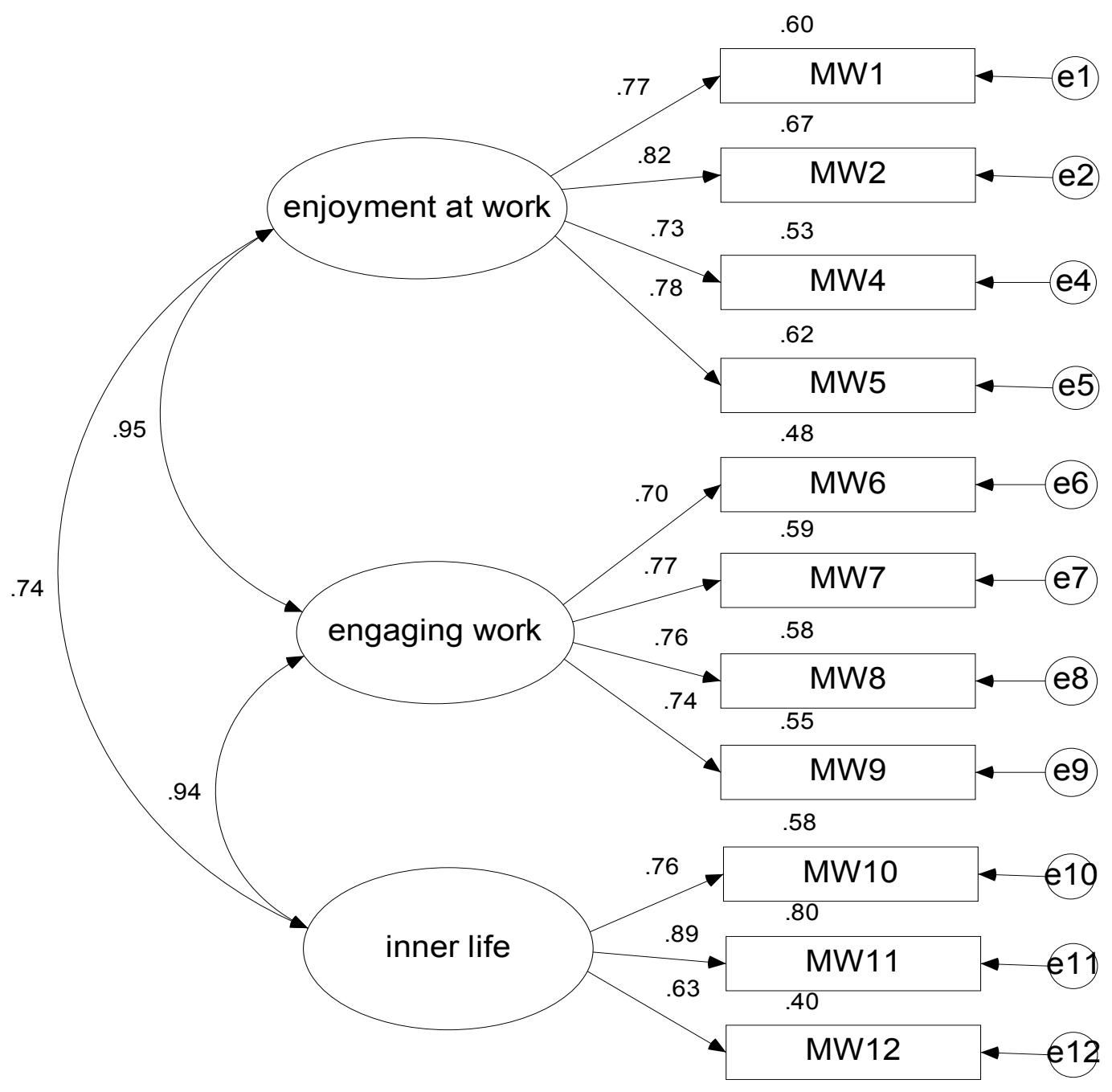

Figure 2. The Modified Model's Fit Evaluation

(4) The Modified Model Test

For overall fit, after deleting MW3in the initial model, it becomes 11 items of Three Factor, called the modified model (see Fig. 2). For overall fit of the modified model, $\chi^{2}=$ $114.05, d f=41, p=.00, \mathrm{GFI}=.92, \mathrm{AGFI}=.88, \mathrm{RMSEA}$ $=.09, \mathrm{IFI}=.95, \mathrm{TLI}=.94$, and $\mathrm{CFI}=.95$. Among them, the fit indicator $\chi^{2}$ and AGFI fail to meet the standard. Others like RMSEA, GFI, IFI, TLI, and CFI all meet the standard. As for Anderson and Gerbing (1988)[31], they claimed that AGFI $\geq 0.80$. As a whole, the overall fit of the modified model is fair.

For the modified model's preliminary fit, the results show that: 1 . in the $\Theta_{\varepsilon}$ matrix entries, the error variances of $\varepsilon_{1}$ to $\varepsilon_{12}$ are all positive; 2. All error variances' $t$ value is between 5.44-10.21, and all achieve significant standard .001. 3. the parameter's standard error is between .04 - .12, not big standard error; 4. the factor loading $\left(\lambda_{1}-\lambda_{12}\right)$ of the latent variable and the indicators is between .63-.89, meeting the standard of more than .50 and less than .95 . For the analysis above, the inspection results all meet the standard, meaning the items' quality is good. Therefore, it is not offending estimation (Hair, Anderson, Tatham, \& Black, 1998) [32].

\section{(5) Fit of Internal of Model Analysis}

For individual reliability, the individual reliability is the square of the indicator's factor loading. There are 11 items in the indicator; that is, $\lambda_{1}-\lambda_{12}\left(\lambda_{3}\right.$ has been deleted). Individual reliability is between .40-.80. Bogozzi and Yi (1988)[29] considered that individual reliability has to be more than .50; that is the indicator's factor loading has to be more than .71. The indicator of this research is MW6 and 12, not reaching the standard, but the remaining 9 meet the standard. The overall results meet the standard.

The latent variable's composite reliability: the three latent variables' composite reliability $\left(\rho_{c}\right)$ are Sense of enjoyment at work .85, sense of engaging work .83, and inner life .81 . The three latent variables meet the standard of more than .60 , meaning that the three latent variables' indicators can detect $81 \%$ of the potential construct. In other words, the three latent variables are basically stable in regard of reflecting the real scores. 
Table 5. Sense of Meaning at Work Scale construct discrimination

\begin{tabular}{|c|c|c|c|c|c|c|c|}
\hline \multirow{2}{*}{ Latent variable } & \multicolumn{3}{|c|}{ Restrictive model (B) } & \multicolumn{3}{|c|}{ nonrestrictive model (A) } & \multirow{2}{*}{$\begin{array}{c}\chi^{2} \text { difference } \\
(\mathrm{B}-\mathrm{A})\end{array}$} \\
\hline & $\rho_{1}$ & $d f$ & $\chi^{2}$ & $\rho$ & $d f$ & $\chi^{2}$ & \\
\hline $\begin{array}{c}\text { Sense of enjoyment at work — sense of engaging } \\
\text { work }\end{array}$ & 1 & 20 & 159.25 & .95 & 19 & 70.65 & $88.60^{*}$ \\
\hline Sense of engaging work — sense of inner life & 1 & 14 & 191.14 & .94 & 13 & 39.33 & $151.81^{*}$ \\
\hline Sense of enjoyment at work-sense of inner life & 1 & 14 & 109.18 & .74 & 13 & 20.52 & $88.66^{*}$ \\
\hline
\end{tabular}

Note: $*$ is that the qui square values of the restrictive model and the nonrestrictive model are bigger than 3.84 , meeting the significant standard, .05 .

The three latent variables' average variance extracted $\left(\rho_{\mathrm{v}}\right)$ are sense of enjoyment at work .60, sense of engaging work .55, and sense of inner life .59. The three latent variables meet the standard of more than .50 , meaning the indicators can reflect the latent variables.

For construct discrimination, this research adopted competitive comparison method (Anderson \& Gerbing, 1988)[31] to inspect the latent variables' construct discrimination: the chi-square difference value $\left(\Delta \chi^{2}\right)$ of the three restrictive models and nonrestrictive model are: 88.60 , 151.81 , and 88.66 , all bigger than the threshold standard 3.84 $(p<.05)$ (see Table 5), meaning that the $\Delta \chi^{2}$ between the restrictive models and nonrestrictive models achieve the significant standard .05. The hypothesis that any two paired latent variables' correlation is absolute correlation $(\rho=1)$ can not be established, and the latent traits of the three latent variable are significantly different.

For the analysis above, fit of internal of model is acceptable. That is. inner quality of the modified model with 11 items of Three Factor is acceptable.

\section{(6) Cross- validity of the Model}

Since the model had been modified, we conducted another investigation for another batch of samples $(N=378)$ to confirm whether the 11 items of Three Factor is stable. The results are $\chi^{2}=172.81, d f=41, p=.00, \mathrm{GFI}=.93$, AGFI $=.88, \mathrm{RMSEA}=.09, \mathrm{IFI}=.95$, TLI $=.94$, and $\mathrm{CFI}=.95$. Among them, $\chi^{2}$ and AGFI do not meet the standard. As Anderson and Gerbing (1988) [31] claimed, AGFI $\geq 0.80$, so the remaining RMSEA, GFI, IFI, TLI, and CFI all meet the standard. As a whole, the modified model is fit. Up to now, Sense of Meaning at Work Scale with 11 items of Three Factor model is established.

\section{Discussion}

The purpose of this research is to develop "Taiwanese Teacher's Sense of Meaning at Work Scale" for related studies. On the developing process:

Firstly, according to the literature analysis results, we found that the theoretical foundation of sense of meaning at work includes values, human needs theory, developmental theory, and spirituality. Since Taiwanese teachers' work duration, and wage are protected by law, and their socio-economic status is high, teaching job becomes a valuable job without the need to care issues like salary, work conditions, permanent job, pension, prestige, and the like. Therefore, this research adopted the perspective of spirituality, focusing on teacher's work leading to enhancement of the personal inner spirituality.

From the perspective of spirituality, we discussed sense of meaning at work from scales that mostly on workplace spirituality. From Table 1, most scales include sense of meaning as one of the main dimensions, such as Ashmos \& Duchon(2000)[2], Milliman, et al. (2003)[17], Sheep(2004)[18], Duchon, \& Plowman(2005)[19], Kinjerski \& Skrypnek(2006)[20], Rego \& e Cunha(2008) [22], Pawar(2009)[23], Petchsawanga \& Duchon(2009)[24], Abdullah \& Ismail(2013)[25], Piryaei \& Zare (2013)[25], and so on. However, these scales have not agreed with one another on sense of meaning at work, because in the pre-test, sense of meaning at work resulted from adopting EFA includes elements like engaging work, Sense of enjoyment at work, mindfulness, Self-work immersion, mystic experience, self-actualization, self- transcendence, inner life, and so on. Since the elements come from different scales, they overlap one another in concept. As for Milliman et al., they considered that sense of meaning at work can be further divided into enjoying work, energized by work, work gives personal meaning and purpose, so we integrated the concepts by the three items. After integrating, they were called sense of engaging work, sense of enjoyment at work, and sense of inner life, respectively. According to these three dimensions and referring to the related items in the scales in Table 1, the draft of the 13 items of Three Factor was compiled.

Next, the draft of the 13 items of Three Factor were rated the relevance of proposed items to make the items more appropriate (Thunborg, von Heideken Wågert, Götell, Ivarsson, \& Söderlund, 2015)[33], and with more content validity. Then, since "teaching (or administration) often makes me energetic" overlaps with "I am often happy when I am teaching (or processing administration)," we deleted the former. Besides, there are 6 items that were modified or remained the same, respectively. With the four experts providing theoretical and practical opinions, the items meet the realistic demand.

Thirdly, we edited the 12 items of Three Factor into questionnaire to conduct the first investigation $(N=235)$, and proceeded correlation coefficient with the data obtained. The results show that it achieves significantly positive correlation. The higher the sense of engaging work level, the higher sense of enjoyment at work and sense of inner life will be, and it is the same in contrast. As Milliman et al. (2003)[17] 
considered, sense of enjoyment at work means work can bring energy and vitality, so that the individual expects to work and love to work. In other words, work is attractive, so if we can engage in work, we will have a sense of happiness and fulfillment, and our life will be richer.

Fourthly, after analyzing correlation coefficient, in order to understand whether the initial model is appropriate or not, we conducted CFA. The results show that the initial model is appropriate as a whole, but the indicator "MW3's" factor loading is too low, only .29, meaning that this item is now influential, and does not meet the standard proposed by Bogozzi and Yi (1988) [29] and Tabachnica and Fidell (2007)[30]. As a result, we deleted this item-- "I often forget time because of teaching (or administration)." Teaching is meaningful, but people who "often forget time because of teaching (or administration)" are rare, because they have to take care of their family as well.

After deleting one item, it becomes 11 items of Three Factor, so we proceeded CFA again, called the modified model. The result presents overall model fit. We further analyzed preliminary fit, the result is unlike what Hair et al. (1998) called "offending estimates." In addition, for fit of internal of model, including (individual reliability, composite reliability, and average variance extracted are fit as well, showing that the inner quality of the modified model is acceptable as well.

Lastly, since the model was modified, we conducted cross- validity for another batch of samples $(N=378)$, called cross-validity of the model. it shows overall model fit, meaning that the model of 11 items of Three Factor is established. It proves that Milliman et al's (2003)[17] claim that sense of engaging work, sense of enjoyment at work, and sense of inner life can function as the factors of sense of meaning at work. From the scales of workplace spirituality, sense of meaning at work is just one of the dimensions, but our research raised it as a variable for scale development, and is supported. On the other hand, sense of engaging work refers to that work itself is attractive to the individual, so it is contains sense of enjoyment at work, which further leads to fulfillment of inner life. This is the causal relationship among the three factors.

Scale development is an iterative, multimethod, qualitative, and quantitative process of item generation, refinement, evaluation, and selection (Selbo - Bruns, Floyd, \& Haynes, 2015)[34]. This scale development began at literature analysis, through expert review, and CFA (including initial model, modified model, cross-validity model), the final confirmation of scale of dense of meaning at work with 11 items of Three Factor is supported, so it can be used by the subsequent researchers as they investigate teachers' sense of meaning at work.

\section{REFERENCES}

[1] M. K .Beigi, F. M. Shahbolaghi, M. Rassafiani, H. A.
Haghgoo, H. Taherkhani, The meaning of work in people with severe mental illness (SMI) in Iran. Medical Journal of the Islamic Republic of Iran, 29, 2015. Retrieved from http://web.a.ebscohost.com/ehost/pdfviewer/pdfviewer?sid= b9ff20ec-a300-4948-b08a-41219a7452be\%40sessionmgr400 $2 \&$ crlhashurl=login.aspx $\% 253$ fdirect $\% 253$ dtrue $\% 2526$ profil e\%253dehost $\% 2526$ scope $\% 253$ dsite $\% 2526$ authtype $\% 253$ dc rawler\%2526jrnl\%253d10161430\%2526AN\%253d1031326 $27 \&$ hid $=4112 \&$ vid $=0$

[2] D. Ashmos, D. P. Duchon, Spirituality at work: A conceptualization and measure. Journal of Management Inquiry, Vol: 19, No, 2, 134-145, 2000. Retrieved from http://ejournal.narotama.ac.id/files/ProQuest_54883215.pdf

[3] C. McLaughlin. Spirituality at work. The Bridging Tree, Vol: $1,11,1998$.

[4] J. Hawley, Reawakening the spirit in work: The power of charming management. San Francisco, CA: Berretta-Koehler, 1993.

[5] O. Aktouf, Management and theories of organizations in the 1990s: toward a critical radical humanism?. Academy of Management Review, Vol: 7, No. 3, 407-431, 1992.

[6] R. Sikka, J. M. Morath, L. Leape, The quadruple aim: care, health, cost and meaning in work. BMJ quality \& safety, bmjqs-2015, 2015. Retrieved from

$\mathrm{http}: / /$ www.hasc.org/sites/main/files/article_the_quadruple aim care health cost and meaning in work $0 \overline{6}-02-150 . \bar{p}$ df

[7] B. A. Allan, R. P. Douglass, R. D. Duffy, R. J. McCarty, Meaningful work as a moderator of the relation between work stress and meaning in life[Abstract]. Journal of Career Assessment, 1069072715599357, 2015.

[8] U. Fasbender, M. Wang, J. B. Voltmer, J. Deller, The meaning of work for post-retirement employment decisions. Work, Aging and Retirement, wav015. doi:10.1093/workar/wav015, 2015.

[9] R. D. Duffy, K. L. Autin, E. M. Bott, Work volition and job satisfaction: Examining the role of work meaning and person-environment fit. The Career Development Quarterly, Vol: 63, No, 2, 126-140, 2015.

[10] M. Ros, S. H. Schwartz, S. Surkiss, Basic individual values, work values, and the meaning of work. Applied psychology Vol: 48, 49-71, 1999.

[11] K. W. Thomas, B. A. Velthouse, Cognitive elements of empowerment. Academy of Management Review, Vol: 15, 666-681, 1990.

[12] G. M .Spreitzer, Psychological empowerment in the workplace: Dimensions, measurement, and validation. Academy of Management Journal, Vol: 38, 1442-1465, 1995.

[13] K. J. Harris, K. M. Kacmar, S. Zivnuska, An investigation of abusive supervision as a predictor of performance and the meaning of work as a moderator of the relationship. The leadership quarterly, Vol: 18, No, 3, 252-263, 2007.

[14] M. E. Mor-Barak, The meaning of work for older adults seeking employment: The generativity factor. International Journal of Aging and Human Development, Vol: 41, 325-344, 1995. 
[15] M. F. Steger, B. J. Dik, R. D. Duffy, Measuring meaningful work: The Work and Meaning Inventory (WAMI). Journal of Career Assessment, 1069072711436160, 2012. Retrieved from

http://scholar.google.com.tw/scholar?q=The+Work+and+Me aning+Inventory\&btnG $=\& \mathrm{hl}=\mathrm{zh}-\mathrm{TW} \&$ as_sdt $=0 \% 2 \mathrm{C} 5$

[16] I. I. Mitroff, E. A. Denton, A study of spirituality in the workplace. MIT Sloan Management Review, Vol: 40, No,4, 83-93, 1999.

[17] J. Milliman, A. J. Czaplewski, J. Ferguson, Workplace spirituality and employee work attitudes: A exploratory empirical assessment. Journal of Organizational Change Management, Vol: 16, No, 4, 426-447, 2003.

[18] M. L. Sheep, Nailing down gossamer: A valid measure of the person-organization fit of workplace spirituality. In D. H, Nagao (Ed.), Best paper proceedings of the sixty-third annual meeting of the Academy of Management, 2004. Retrieved from http://ejournal.narotama.

ac.id/files/Person-organization\%20fir\%20\&\%20sprituality.p df

[19] D. T. Duchon, A. Plowman, Nurturing the spirit at work: Impact on work unit performance. The Leadership Quarterly, Vol: 16, 807-833, 2005

[20] V. Kinjerski, B. J. Skrypnek, Creating organizational conditions that foster employee spirit at work. Leadership \& Organization Development Journal, Vol: 27, No, 4, 280-295, 2006.

[21] T. W. Moore, W. J. Casper, An examination of proxy measures of workplace spirituality: A profile model of multidimensional constructs. Journal of Leadership \& Organizational Studies, Vol: 12, No, 4, 109-118, 2006.

[22] A. Rego, M. P. e Cunha, Workplace spirituality and organizational commitment: An empirical study. Journal of organizational change management, Vol: 21, No, 1, 53-75, 2008

[23] B. S. Pawar, Individual spirituality, workplace spirituality and work attitudes: An empirical test of direct and interaction effects. Leadership \& Organization Development Journal, Vol: 30, No, 8, 759-777, 2009.
[24] P. Petchsawang, D. Duchon, Measuring workplace spirituality in an Asian context. Human Resource Development International, Vol: 12, No, 4, 459-468, 2009

[25] A. G. K. Abdullah, A. Ismail, Validating and standardization the Scale of Malay Version Workplace Spirituality from Malaysian school settings. International Journal of Asian Social Science, Vol: 3, No, 6, 1418- 1430, 2013.

[26] S. Piryaei, R. Zare, Workplace spirituality and positive work attitudes: The moderating role of individual spirituality. Indian Journal of Economics and Development, Vol: 1, No, 4, 91-97, 2013.

[27] C. J. Fullagar, E. K. Kelloway, Flow at work: An experience sampling approach. Journal of occupational and organizational psychology, Vol: 82, No, 3, 595-615, 2009.

[28] R. E. Schumacker, R. G. Lomax, A beginner's guide to structural equation modeling. Mahwah, NJ: Lawrence Erlbaum Associates, 1996.

[29] R. P. Bagozzi, Y. Yi, On the evaluation of structural equation models. Academic of Marketing Science, Vol: 16, 74-94, 1988.

[30] B. G.Tabachnica, L. S. Fidell, Using multivariate statistics(4 ed.). Needham Heights, MA: Allyn and Bacon, 2001.

[31] J. C. Anderson, D. W. Gerbing, Structural equation modeling in practice: A review and recommended two-step approach. Psychological bulletin, Vol: 103, No, 3, 411-423, 1988.

[32] J. F. Hair, R. E. Anderson, R. L. Tatham, W. C. Black. Multivariate data analysis (5th ed.). Englewood Cliffs, NJ: Prentice-Hall, 1998.

[33] C. Thunborg, P. von Heideken Wågert, E. Götell, A. B. Ivarsson, A. Söderlund, Development of a new assessment scale for measuring interaction during staff-assisted transfer of residents in dementia special care units. BMC Geriatrics, Vol: 15, No, 6, 1-8, 2015.

[34] A. Selbo - Bruns, F. J.Floyd, S. N. Haynes, Scale Development[Abstract]. The Encyclopedia of Clinical Psychology, 2015. DOI: 10.1002/9781118625392.wbecp186 